\title{
Bromeliads in Caatinga: an oasis for invertebrates
}

\author{
Priscila Islair ${ }^{1}$ \\ Karine Santana Carvalho ${ }^{1}$ \\ Fabio Cop Ferreira ${ }^{2}$ \\ Juliana Zina ${ }^{1 *}$ \\ Departamento de Ciências Biológicas, Universidade Estadual do Sudoeste da Bahia \\ Rua José Moreira Sobrinho, s/n, CEP 45206-190, Jequié - BA, Brasil \\ ${ }^{2}$ Departamento de Ciências do Mar, Universidade Federal de São Paulo, \\ Campus Baixada Santista Avenida Almirante Saldanha da Gama, 89, CEP 11030-400, Ponta da Praia, Santos - SP, Brasil \\ * Autor para correspondência \\ juzina74@gmail.com.br
}

Submetido em 11/05/2014

Aceito para publicação em 18/11/2014

\section{Resumo}

Bromélias na Caatinga: um oásis para os invertebrados. A família Bromeliacea apresenta diversas adaptações que promovem a ocorrência de seus representantes em muitas fitofisionomias, incluindo a Caatinga. A forma de suas folhas em roseta gera uma cisterna ou tanque, onde há um acúmulo de água rica em nutrientes. Esse arranjo fornece um micro-habitat para reprodução, alimentação e desenvolvimento larval de muitos invertebrados. Com o objetivo de invetariar a fauna associada de invertebrados e testar a hipótese de que sua composição varia sazonalmente, realizamos duas campanhas durante os períodos de chuva (Fevereiro de 2011) e seca (Agosto de 2012) na Floresta Nacional (Flona) de Contendas do Sincorá, município de Contendas do Sincorá, estado da Bahia, Brasil. Delimitamos 15 parcelas de $5 \mathrm{~m}$ x $5 \mathrm{~m}$ ao longo de uma trilha de $355 \mathrm{~m}$ nas quais coletamos duas bromélias terrestres da espécie Aechmea bromeliifolia por parcela. Posteriormente analisamos a riqueza, abundância e composição de invertebrados em cada planta. A riqueza de táxons não diferiu entre as estações e foi considerada alta para a Caatinga. A abundância e a composição, entretanto, variaram entre as estações chuvosa e seca. O presente estudo mostrou a importância das bromélias para a comunidade de invertebrados da Caatinga local, pois representam o único recurso de água disponível. Nossos resultados fornecem um "insight" para estudos mais profundos das interações planta-animal e para a conservação de animais e plantas da Caatinga.

Palavras-chave: Aechmea bromeliifolia; Bromeliaceae; Conservação; Fauna associada; Semiárido brasileiro

\section{Abstract}

The Bromeliaceae family exhibits several adaptations that allow the occurrence of its members in different physiognomies, including the Caatinga. The arrangement of leaves in rosette forms a cistern or tank, in which nutrient-rich water accumulates. This provides a microhabitat for reproduction, feeding, and larval development of many invertebrates. The aim of this study was to survey the bromeliad-associated invertebrate fauna to test the hypothesis of seasonal changes in community composition. We conducted two surveys in the rainy (February, 2011) and dry (August, 2012) seasons in the Floresta Nacional (Flona) of Contendas do Sincorá, municipality of Contendas do Sincorá, Bahia state, Brazil. We delimited fifteen $5 \mathrm{~m}$ x $5 \mathrm{~m}$ sampling plots along a $355 \mathrm{~m}$ trail. 
Two terrestrial bromeliads (Aechmea bromeliifolia) were collected per plot. Invertebrate fauna were identified and richness, abundance and composition were analyzed. The richness of taxa did not differ between seasons and was considered high for Caatinga. Abundance and composition differed between the rainy and dry seasons. The present study demonstrates the importance of bromeliads as available water resources for the local invertebrate community. Our findings also provide a framework for more in-depth studies on animal-plant interactions, and for the conservation of Caatinga animals and plants.

Key words: Aechmea bromeliifolia; Associated fauna; Brazilian semiarid; Bromeliaceae; Conservation

\section{Introduction}

Caatinga is a vegetation mosaic, characterized by thorny shrubs and seasonally dry forests. The characteristics of Caatinga vegetation are the result of interactions among the soil types and climate of each region (ANDRADE-LIMA, 1981). Therefore, its classification into phyto-physiognomies is extremely difficult, although some proposals have been presented (ANDRADE-LIMA, 1981; RODAL; SAMPAIO, 2000). In general, Caatinga is characterized by unpredictable rain, with lengthy dry periods in some regions (KROL et al., 2001). This creates a selective pressure on the local biota, and as a result, plant species with adaptations to water deficiency (small size, seasonal deciduous, with annual cycles, succulence, presence of spines and thorns) predominate in Caatinga (GIULIETTE et al., 2003; ROCHA et al., 2004). Like plants, animal species typical of Caatinga also exhibit morpho-physiological adaptations that allow them to survive during dry periods (RODRIGUES, 2003; NAVAS et al., 2004).

Among the plants that present adaptations to xeric habitats, the Bromeliaceae family exhibits a significant number of endemic Caatinga species (GIULIETTE et al., 2003). This family comprises terrestrial, saxicolous, and epiphytic species that generally exhibit simple leaves in rosette, and can tolerate long dry periods (LEME, 1984). According to Benzing and Renfrow (1974), the arrangement of leaves in rosette forms a cistern or tank that accumulates nutrient-rich water. The nutrients originate from decomposition of detritus from external sources accumulated in the phytotelma (central tank), such as leaves, twigs, flowers, fecal matter, and live organisms (BENZING; RENFROW, 1974). The water accumulated in the rosette can be considered an "isolated limnological habitat", a microhabitat, or a microcosm that can be used by several animal and plant species (PICADO, 1913;
OLIVEIRA et al., 1994; MESTRE et al., 2001). Bromeliads provide a variety of compartments and ecological gradients for animal communities (RICHARDSON, 1999). Thus, bromeliads play an important ecological role in their habitats (BENZING, 2000) by providing an oasis for reproduction, feeding, and development of many species of invertebrates and vertebrates (ROCHA et al., 1997; RICHARDSON, 1999; JUNCÁ; BORGES, 2002).

Among the invertebrates associated with bromeliads, several species of insects, spiders, crustaceans, platyhelminthes, nemathelminthes, oligochaetes, mollusks, and myriapods have been reported (MESTRE et al., 2001). The richness, abundance, and composition of organisms present in bromeliads are regulated mainly by availability of organic matter, in concordance with "bottom-up" theory (FRANK; LOUNIBOS, 1983; KITCHING, 2000; 2001).

Most studies on phytotelm habitats have focused on the micro and macrofauna of rainforest bromeliads (HADEL; CARVALHO, 1988; LOPEZ et al., 1998). No similar studies have been conducted in semi-arid regions where bromeliads serve as small oasis during certain times of the year. Many studies have focused mainly on inventory (WITTMAN, 2000; MESTRE et al., 2001), yet few present more in-depth analysis of the effect of plant or habitat characteristics on associated fauna (RICHARDSON; HULL, 2000; COGLIATTICARVALHO et al., 2001).

The present study aimed to evaluate the structure of the invertebrate community associated with the phytotelma of the bromeliad species Aechmea bromeliifolia (Rudge) in a conservation area of Caatinga in central-southern Bahia, Brazil. The approach consisted of examination of (plant-associated) species and biotic factor seasonality, as well as abiotic factors responsible for the observed structure. Studies utilizing 
this approach are of increased importance in poorly known and extensive areas, particularly those under human influence and/or disturbance, such as Caatinga.

\section{Material and Methods}

\section{Study site}

This study was conducted along a $1.5 \mathrm{~km}$ trail (135'27.4”S; 41 06'57.6”'W, $377 \mathrm{~m}$ above sea level), located in the Floresta Nacional (Flona) Contendas do Sincorá, in the Municipality of Contendas do Sincorá, central-southern Bahia, Brazil.

In the Contendas do Sincorá region, the rainy period occurred between February and May 2010, and between October and February 2011, with rain peaks between November and December. The dry season occurred between May and September 2010 (CPTEC/ INPE, 2012).

\section{Sampling procedures}

We delimited 15 plots $(5 \mathrm{~m} \times 5 \mathrm{~m}$ ) along $355 \mathrm{~m}$ of a trail known as "trail of bromeliads", chosen due to the high bromeliad abundance. Alternate plots were established (i.e., on the left and right sides of the trail) $20 \mathrm{~m}$ apart. We counted the number of bromeliads per plot, and for the eight plots where Aechmea bromeliifolia bromeliads were present, two individuals were randomly collected for survey of invertebrate fauna. The samples were performed in the wet (February 2011) and dry (August 2012) seasons, so that we analyzed 32 bromeliads. Bromeliad morphological parameters (i.e., number of leaves, height, diameter of the rosette, maximum height and diameter, volume of stored water) were measured with the plant on the substrate, in order to examine possible effects of these factors on the richness and abundance of invertebrates. Water volume was measured by carefully removing the bromeliad from the substrate and transferring it to a $100 \mathrm{~L}$ plastic bag, where the water content was emptied. The water was later transferred to a $1000 \mathrm{~mL}$ graduated cylinder. Parameters of the water stored in the phytotelmata ( $\mathrm{pH}$ and temperature) were also measured. Additionally, we classified the amount of detritus inside the plant on a scale from 1 to 5 , based on the transparency of the water and the presence of dry leaves. After these measurements, plants were collected by hand, and the water in the phytotelmata was placed in plastic containers with ethanol P.A. (100\%) for later analysis of biological content.

The collected bromeliads were defoliated, and each leaf washed to remove all invertebrates. The biological material was fixed and preserved in $70 \%$ ethanol, and all invertebrates were morphotyped and identified to family level, except for those in subclass Oligochaeta. After identification, all families were classified into functional groups: collectors, filtering collectors, shredders, predators, and scrapers, according to Merrit et al. (1996) and Gullan and Cranston (2005).

Specimens were deposited in the invertebrate collection at the Universidade Estadual do Sudoeste da Bahia, Jequié campus, Bahia, Brazil.

\section{Data analysis}

To examine the distribution pattern of bromeliads in the study area, we applied Morisita's index (Id) (BROWER; ZAR, 1984), which indicates whether the distribution is uniform $(0 \geq \mathrm{Id}<1)$, random $(\mathrm{Id}=1)$ or clustered (Id $>1)$. To test if Id was significantly different than 1, we used the F test.

Adequacy of sampling effort was examined based on accumulation curve pattern, constructed with 1000 randomizations and using the Mao Tao method. We used data on the presence or absence of families, with each bromeliad as a sampling unit. Five richness estimators were used: Chao II, Bootstrap, Jackknife 1, Jackknife 2 and Ice (SANTOS, 2003). Differences in richness and abundance of bromeliad taxa during the dry and rainy seasons were compared with a t test and the corresponding non-parametric Mann-Whitney test, respectively (ZAR, 1996).

Invertebrate community composition was analyzed using non-metric multidimensional scaling analysis (NMDS) based on the similarity matrix obtained with the Bray Curtis index. Data on ants were not included, as the abundance of individuals was the ecological parameter chosen to examine seasonality, and recruitment activity in this group would have compromised the analysis. 
To test the hypothesis that community composition is influenced by seasonality, we performed a non-parametric analysis of similarity (ANOSIM) (MCCUNE; GRACE, 2002) based on 1000 randomizations. In ANOSIM, a significant result suggests that community similarity is higher within than among the seasons, so that community composition is influenced by dry and rainy periods.

To determine which families might be responsible for the seasonal pattern observed, we obtained Pearson's correlation coefficient for the values of the axis 1 obtained by NMDS, and the log-transformed values of abundance of each family found in bromeliads (LEGENDRE; LEGENDRE, 2012).

To determine which variables associated with bromeliads influence invertebrate richness and abundance, we performed multiple regressions using parameters of bromeliads and tank water (see Sampling procedures). Richness and abundance were log transformed to meet the assumptions of normality and residual homogeneity of variance (ZAR, 1996). In all statistical tests, the significance level was set at $\mathrm{P}<0.05$. In multiple regression models, the predictor variables must not be correlated with each other (collinearity assumption). This assumption was tested by the variance inflation factor - VIF. Chatterjee and Hadi (2006) recommend that for each predictor, a VIF higher than 10 should be investigated for problems with collinearity.

\section{Results}

\section{Bromeliad density}

The distribution of Aechmea bromeliifolia varied along the trail, and between the dry and wet seasons. In some plots, no plants were found. Bromeliad density ranged from 1.36 to 1.04 plants per $\mathrm{m}^{2}$ in the dry and rainy seasons, respectively. Aechmea bromelifolia individuals were arranged in dense clusters with an average of four groups of plants per plot, each with approximately 15 bromeliads. The clustered distribution pattern was confirmed by the Morisita's dispersion index, which yielded a value significantly higher than $1(\mathrm{Id}=$ $2.46, \mathrm{~F}=54.04, \mathrm{P}<0.05)$.

\section{Richness, abundance, taxonomic composition and seasonality}

The species accumulation curve reached the asymptote, and the richness values obtained were the same as those estimated by the indices (Figure 1).

In the 32 collected bromeliads, 1,738 invertebrates were recorded. Of all collected individuals, only 64 were in the pupal stage; the remaining individuals were in larval stages. Invertebrates associated with phytotelmata were represented by seven orders (17 families) and 1 subclass (1 family). The orders Araneae and Diptera had the greatest number of families present (Table 1).

Taxonomic richness did not differ between seasons $(\mathrm{t}=1.47, \mathrm{P}=0.15)$. However, abundance differed between rainy and dry periods (1,298 and 440 individuals, respectively) $(\mathrm{U}=39.5, \mathrm{P}<0.001)$. Diptera was the most abundant order in the rainy season, and Coleoptera was the most abundant in the dry season. Combined data (dry and rainy seasons) show that Diptera was the most abundant order, followed by Coleoptera. The subclass Oligochaeta represented $12.31 \%$ of the total number of organisms, possibly due to collection during the rainy season. Hymenoptera was the fourth most abundant order, due to the presence of an ant nest in a single bromeliad.

The NMDS analysis revealed differences in invertebrate assemblages between the two seasons (Figure 2). Of the 16 bromeliads sampled in the dry season, 15 were included in the NMDS analysis. We excluded one outlier, in which we only found individuals belonging to orders Araneae and Hymenoptera. The abundance of the latter taxon was high due the presence of an ant nest within the bromeliad. With axis 1 as a reference, 14 of the 15 bromeliads in the dry season were clustered in the negative portion of axis 1 , while those collected in the rainy season were clustered in the positive portion of this axis. An overlap was observed between bromeliads collected in the dry and rainy seasons. This overlap was due to two bromeliads collected during the dry seasons with a high abundance of Ceratopogonidae (Diptera). ANOSIM confirmed a seasonal pattern in assemblage structure $(\mathrm{R}=0.455, \mathrm{P}$ $<0.001)$. 
FIGURE 1: Accumulation curve of invertebrates families recorded in 32 tank bromeliads (Aechmea bromeliifolia) collected in dry and rainy seasons in Flona Contendas do Sincorá, Contendas de Sincorá municipality, Bahia, Brazil. Richness indices are included, and points represent mean number of taxa and corresponding standard deviations.

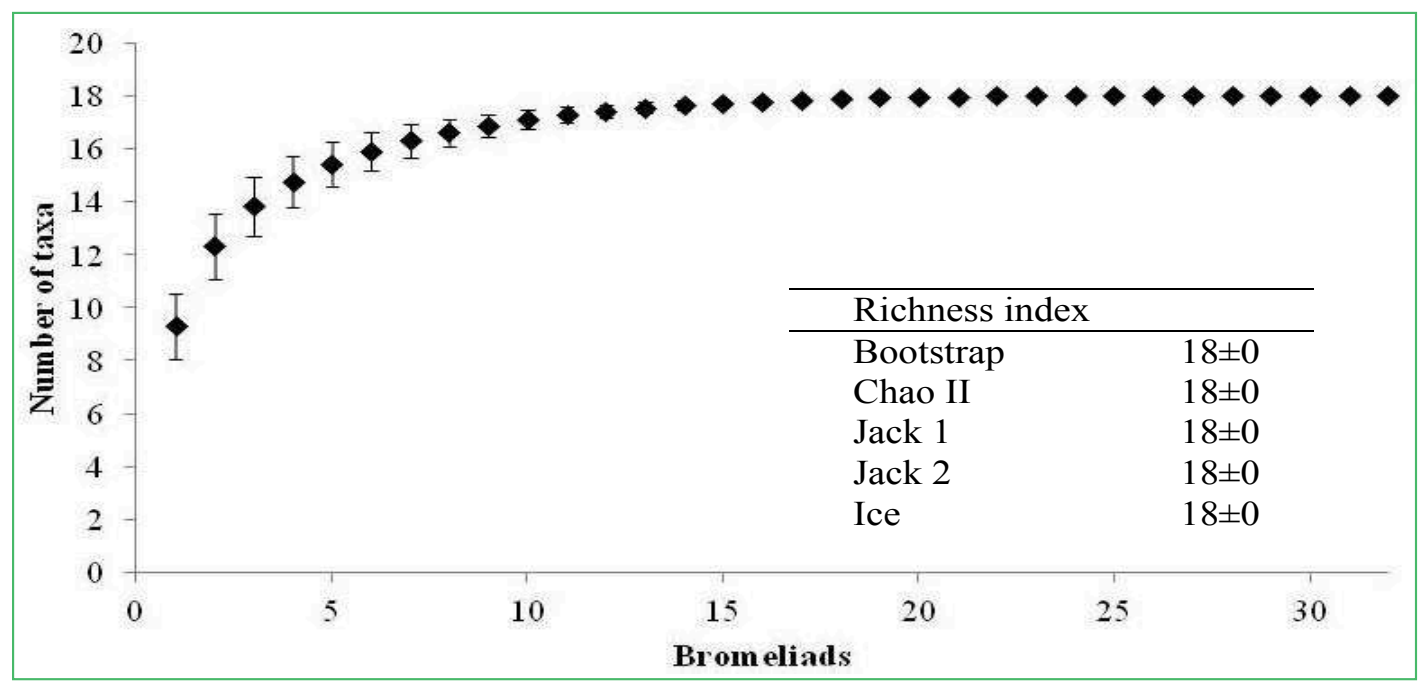

TABLE 1: Description of invertebrates collected in tank bromeliads (Aechmea bromeliifolia) in August 2010 and February 2011 in Flona Contendas do Sincorá, Contendas de Sincorá municipality, Bahia, Brazil.

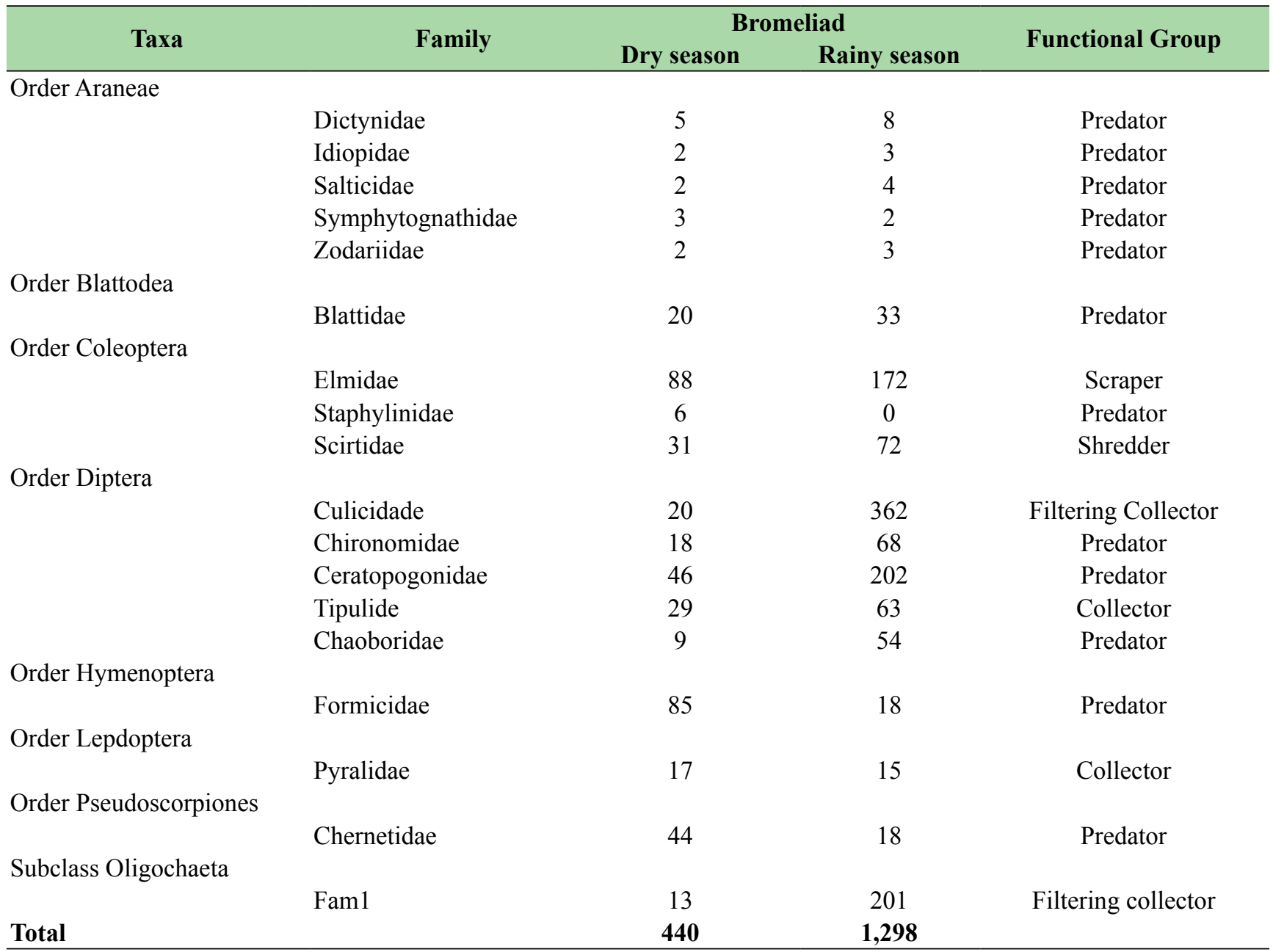


The correlation analyses between axis 1 and the log-transformed abundance values for each family were significant for Culicidae $(\mathrm{P}<0.001)$, Ceratopogonidae $(\mathrm{P}=0.002)$, Elmidae $(\mathrm{P}=0.034)$ and Oligochaeta $(\mathrm{P}=$ 0.001 ), indicating that the abundance of these families was responsible for the segregation of the data obtained for the dry and rainy seasons.

FIGURE 2: NMDS analysis (Bray-Curtis index) comparing abundance of different invertebrates in bromeliads (Aechmea bromeliifolia) in the dry (black circles, continuous line) and rainy (open circles, dashed line) seasons in Flona Contendas do Sincorá, Contendas de Sincorá municipality, Bahia, Brazil. Axis 1 was responsible for the seasonal pattern in the structure of assemblages. Stress $=0.2032$.

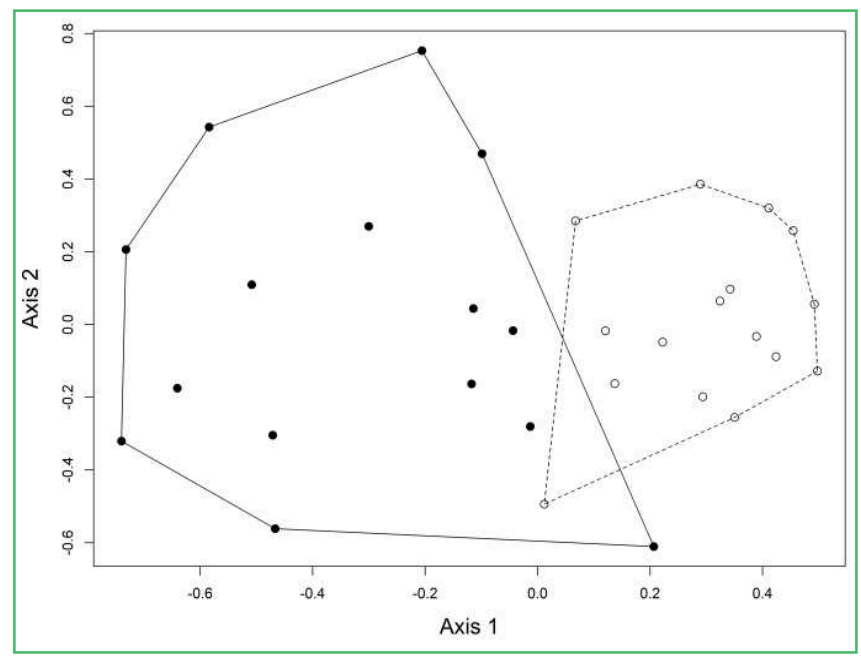

\section{Analysis of abiotic and morphometric} factors

Concerning the multiple regression models, the VIFs for all predictor variables were smaller than 3 . Thus, collinearity did not prevent interpretation of the regression models. The regressions of the environmental descriptors with species richness and abundance were not significant $\left(\mathrm{F}_{(9,21)}=0.670, \mathrm{p}=0.726\right.$ and $\mathrm{F}_{(9,21)}=1.675, \mathrm{P}=0.158$, respectively) (Table 2). However, the coefficients associated with the diameter of the rosette, number of leaves, and water temperature were significantly negative for abundance $(\mathrm{P}<0.05)$, indicating that an increase in these variables may result in a decrease in invertebrate abundance.

\section{Analysis of functional groups}

Based to the classification in functional groups adopted in the present study, predators were the most represented group, followed by collectors (Table 1).

\section{Discussion}

In the present study bromeliad density was high, even when compared to Atlantic Forest areas. Freitas et al. (2000) recorded a bromeliad density of 1.04

TABLE 2: Multiple regression estimators of the evaluated parameters (for bromeliads and tank water) and the natural logarithm of invertebrate family richness $\mathrm{F}_{(9,21)}=1.675, \mathrm{P}=0.158, \mathrm{R}_{\text {adjusted }}^{2}=0.17$. Significant coefficients associated with bromeliad variables are presented in bold text.

\begin{tabular}{lcccc}
\hline \multicolumn{1}{c}{ Variable } & Estimator & Standard deviation & $\mathbf{t}$ & $\mathbf{p}$ \\
\hline Intercept & 16.685 & 4.526 & 3.686 & 0.0014 \\
Rosette diameter & $\mathbf{- 0 . 0 2 4}$ & $\mathbf{0 . 0 1 1}$ & $\mathbf{- 2 . 1 1 3}$ & $\mathbf{0 . 0 4 6 8}$ \\
Volume of stored water & -0.003 & 0.002 & -1.418 & 0.1709 \\
Maximum height of bromeliad & -0.029 & 0.016 & -1.812 & 0.0844 \\
Rosette height & 0.021 & 0.032 & 0.658 & 0.5175 \\
Maximum width of bromeliad & 0.010 & 0.010 & 1.008 & 0.3248 \\
Number of leaves & $\mathbf{- 0 . 1 8 0}$ & $\mathbf{0 . 0 8 4}$ & $\mathbf{- 2 . 1 5 3}$ & $\mathbf{0 . 0 4 3 1}$ \\
pH & -0.278 & 0.188 & -1.479 & 0.1541 \\
Level of detritus & 0.198 & 0.146 & 1.354 & 0.1902 \\
Water temperature & $\mathbf{- 0 . 2 6 7}$ & $\mathbf{0 . 1 0 5}$ & $\mathbf{- 2 . 5 5 2}$ & $\mathbf{0 . 0 1 8 6}$ \\
\hline
\end{tabular}


plants $/ \mathrm{m}^{2}$ in the restinga (i.e., a distinct type of Brazilian coastal tropical/subtropical moist forest) of Jurubatiba in Macaé, Rio de Janeiro state. However, Reitz (1957) recorded a bromeliad density of 13.5 plants $/ \mathrm{m}^{2}$ in the restinga of Azambuja, Brusque municipality, in Santa Catarina state. The trail in this study does not represent the phytophysiognomy of the entire Flona, as it was chosen due to high abundance of bromeliads. Even if density were lower, these plants would be one of the few water resources available to the local fauna, as most water bodies in the surrounding area were dry during the dry season. Within plots, bromeliads were highly clustered, as confirmed by the dispersion indices. This same pattern was obtained by Freitas et al. (2000) and might be associated with factors intrinsic to the plant, such as vegetative propagation, the most common mode of reproduction in this species (HENRIQUES et al., 1984; COGLIATTI-CARVALHO; ROCHA, 2001).

The species accumulation curve reached an asymptote. Curve stabilization in invertebrate studies is not very common due to the high diversity of the group (RICHARDSON, 1999; GESING, 2008). However, the present study was conducted with a specific community (bromeliads) and environment/landscape (Caatinga), and richness estimators suggest that sampling effort was adequate.

Invertebrate (individual) abundance was higher in our study site than what has been reported in phytophysiognomies of other regions (e.g., 1500 in semideciduous Atlantic forest (COELHO et al., 2005) and 1639 in restinga (MESTRE et al., 2001). As they are the only water resources available during the dry season, these plants apparently play a role as natural nurseries for several families of invertebrates in Caatinga, since these animals depend on water sites for reproduction and survival of larvae. Further, the majority of the invertebrates found associated with tank bromeliads are specific to still water sources (ROMERO, 2005; ROCHA et al., 1997).

Invertebrate richness was similar in dry and rainy seasons, perhaps because the resource used for reproduction (water in the phytotelma) was available in both seasons. However, in the dry season water temperature was higher, which could have interfered in the survival and consequently abundance of larvae recorded in the sampled bromeliads.

The regression models for richness and abundance were not statistically significant. However, for invertebrate abundance, three variables had statistically significant regression coefficients (rosette diameter, number of leaves, and water temperature). This apparent contradiction (a non-significant regression model with significant regression coefficients) may occur when there is collinearity among predictor variables (CHATTERJEE; HARDI, 2006). We did not detect collinearity among predictors (all VIFs were smaller than 3), so we find it prudent that future studies consider these variables as possible determinants of invertebrate abundance within bromeliads in the Caatinga region. The influence of these three variables on invertebrate abundance may be a reflection of higher insolation, as some bromeliads exposed to higher insolation levels had more leaves, higher capacity of accumulating water, and higher water temperature in the plant (GUIMARÃESSOUZA et al., 2006, MONTERO et al., 2010). In addition, future studies might also consider higher sample sizes in order to increase the probability of detection of significant effects.

Phytotelmata-associated invertebrates were represented by eight taxa, fewer than those found in other studies and in different biomes (18 orders and 61 families in Chaco (MONTERO et al., 2010); 29 families in semideciduous Atlantic forest (COELHO et al., 2005). Species richness in Caatinga is probably lower, as suggested by patterns observed for other animals and plant groups in this biome (LEAL et al., 2003).

It is possible that the diversity and abundance of families recorded in the phytotelma reflects the same patterns found in the community outside of the plants. However, in the present study hymenopteran richness was higher outside than inside the bromeliads (see CALLISTO; ESTEVES, 1988). The occurrence of this order in phytotelmata, represented solely by the Formicidae family, may be considered incidental since it was observed in only one bromeliad and during the dry season only. Oliveira et al. (1994) did not consider ants as typical fauna of bromeliads, and suggested that their high frequency could be due to the foraging behavior of 
nearby colonies. Further studies in or near bromeliads may reveal if the community pattern observed in phytotelmata corresponds to an extension of the pattern observed in the habitat.

The higher richness indices recorded for Araneae and Diptera may be due to the habits, habitats and reproductive biology of the species in these groups. Spiders, especially those from the Salticidae family, exhibited strict associations with bromeliads, using them as mating and reproduction sites, and as shelter against predators (ROMERO, 2005). In addition, the representatives of the order Araneae generally used bromeliads as foraging sites, acting in the population balance of insects and other invertebrates associated with these plants (ROMERO, 2005). High richness indices of Diptera families may be explained by the larval adaptations of different species to adverse environmental conditions, such as high temperatures and wide variations in water regime (SOUTO et al., 2008). In addition, they exhibit adaptations in morphology and diet (most dipterans are collectors and filtering collectors of fine organic matter, and are sometimes predators), and reproduction, allowing them to colonize and reproduce in a wide variety of habitats (OSPINA-BAUTISTA et al., 2004). The high abundance of dipterans recorded during the rainy season might be associated with water availability for reproduction (SILVA et al., 2004). These results are similar to those observed by Souto et al. (2008) in an area of Caating in Paraíba, by Coelho et al. (2005) in the semideciduous Atlantic forest, and by Montero et al. (2010) in Chaco. For Richardson and Hull (2000), the most relevant reproductive adaptation in this order is oviposition into the same habitat where larvae develop, combined with high capacity for dispersion by flight.

Wittman (2000), Mestre et al. (2001), and Juncá and Borges (2002) observed that the most abundant order of bromeliad-associated invertebrates was Coleoptera. In the present study, this was true only in the dry season. Differences in abundance between dry and rainy seasons were not as prominent as those observed for other orders, especially Diptera. This might be associated with the ability of Coleoptera species to survive in the adverse conditions of Caatinga. The increased abundance of coleopterans in the rainy season might be explained due to the association of these insects with phytotelmata water for foraging (i.e., for algae and aquatic fungi) (COSTA et al., 1988).

One hypothesis for the increase in abundance of dipterans and coleopterans in the dry season is the interactions between larvae of these taxa. Three families of dipterans are potentially predators of invertebrates (Charboridae, Chironomidae, and Ceratopogonidae) (CALLISTO; ESTEVES, 1988). The abundance of Charboridae increases considerably during the rainy season, which may decrease numbers of coleopterans and other larvae due through predation. Some authors classify Chironomidae as omnivores/collectors (MERRIT et al., 1996; SILVA, 2007). Regardless, it is agreed Chironomidae members have high flexibility regarding diet and habitat selection, making them one of the most successful groups among aquatic insects, with high potential for colonization (SILVA, 2007). Another hypothesis describes higher fitness and/or competitive skills of these taxa when they are most abundant (rainy season). Further observations of interespectific relationships inside bromeliads are needed to test these hypotheses.

Other groups of predators, including pseudoscorpiones, hymenopterans, and blattodeans, as well as parasites, typically have constant abundances, as they directly depend on the presence of other invertebrates rather than productivity gradients or availability of organic particles (VANNOTE et al., 1980). According to Guimarães-Souza et al. (2006), invertebrate larvae play an important role in Bromeliaceae trophic webs, as most are detritivores and scrapers, and are both important primary consumers and food sources for other trophic levels.

The NMDS analysis supports the data on family abundance in the dry and rainy seasons, confirming the existence of seasonality. The correlation analysis indicates that abundance of two dipteran families, one coleopteran family, and one family of the subclass Oligochaeta were responsible for the segregation of the data in dry and rainy seasons, with higher abundance in the latter. The abundance of these groups during the rainy season might be explained by two hypotheses. First, 
physiological and ecological constraints imposed by the absence of rains and high temperatures during the dry season could limit abundance. Second, the relationship between predation and competition among species in the phytotelma could impact abundance differently among seasons.

A main characteristic of Caatinga is unpredictability of rain throughout the year, which is a constraining factor for habitat occupation by some animals. During the rainy season, water availability relieves the selective pressure imposed by the absence of this resource, favoring reproduction and population increases. As observed by Oliveira and Frizzas (2008) and Pinheiro et al. (2002) in areas of Cerrado, rain favors increase in insect abundance, and as such invertebrate fauna exhibit a seasonal distribution pattern with higher abundance during the rainy season. This reinforces the importance of phytotelmata as a reproductive resource in seasonal habitats.

The present study shows the importance of bromeliads to the associated animal community, especially in a phyto-physiognomy with long periods of drought throughout the year. Bromeliads are the only water resource available during certain times of the year, and may act as small oasis for reproduction, feeding, and developing of many invertebrate species. Phytotelmatainvertebrate associations might be even more diverse than is currently known, as they comprise a variety of organisms, including immature, adult (Araneae), semiaquatic, or terrestrial (Formicidae) animals. Many of the invertebrates recorded in bromeliads in this study belong to distinct functional groups, and as such they play important roles in this microhabitat, forming a chain of complex interactions. In addition, the present study may be a framework for more in-depth studies on this subject, and may contribute to the conservation of bromeliads and invertebrates of Caatinga.

\section{Acknowledgements}

We thank Vanderlan Sousa, Anselmo Souza, Ana Biggi, Ana Paula Barbosa, Roseane Nunes, Arheta Almeida and Ariela Santos Souza for assistance in the field. We are grateful to Paulo Borges, Júlia Romão, Marcos Augusto Ferraz Carneiro and Ivan Cardoso do Nascimento for assistance with identification of biological material and André Teixeira da Silva for valuable suggestions on earlier drafts of this manuscript. We thank Anne Taffin D'Heursel Baldisseri and Jennifer Ann Breaux for translating the manuscript.

\section{References}

ANDRADE-LIMA, D. The Caatingas Dominium. Revista Brasileira de Botânica, São Paulo, v. 4, p. 149-153, 1981.

BENZING, D. H. Bromeliaceae: profile of an adaptive radiation. Cambridge: Cambridge University Press, 2000. 690 p.

BENZING, D. H.; RENFROW, A. The mineral nutrition in Bromeliad. Botanical Gazette, Chicago, v. 135, p. 281-288, 1974.

BROWER, J. E.; ZAR, J. H. Field and laboratory methods for general Ecology. Dubuque: W. C. Brown Publishers, 1984. 226 p.

CALLISTO, M.; ESTEVES, F. A. Categorização funcional dos macroinvertebrados bentônicos em quatro ecossistemas lóticos sob influência das atividades de uma mineração de bauxita na Amazônia Central (Brasil). In: NESSIMIAN, J. L.; CARVALHO, A. L. (Ed.). Ecologia de Insetos Aquáticos - Series Oecologia Brasiliensis. Rio de Janeiro: PPGE-UFRJ, 1988. p. 224-233.

CHATTERJEE, S.; HADI, A. S. Regression analysis by example. 4 ed. New Jersey: Jonh Willey \& Sons, 2006. 375 p.

COELHO, M. S.; SANTOS, R. L.; ALMEIDA, M. G.; ARAUJODE-ALMEIDA, E. Macrofauna associada à fitotelmo de Hohenbergia sp. (Bromeliaceae) em fragmento de mata atlântica da escola agrícola de Jundiaí, Macaíba (RN, Brasil). In: CONGRESSO DE ECOLOGIA DO BRASIL, VII, 2005, Caxambu. Resumos ... Caxambu: SBE, 2005. Versão eletrônica.

COGLIATTI-CARVALHO, L.; DE FREITAS, A. F. N.; DA ROCHA, C. F. D.; SLUYS, M. V. Variação na estrutura e na composição de Bromeliaceae em cinco zonas de restinga no Parque Nacional da Restinga de Jurubatiba, Macaé, RJ. Revista Brasileira de Botânica, São Paulo, v. 24, n. 1, p. 1-9, 2001.

COGLIATTI-CARVALHO, L.; ROCHA, C. F. D. Spatial distribution and preferential substrate of Neoregelia johannis (Carriére) L.B. Smith (Bromeliaceae) in a disturbed area of Atlantic Rainforest at Ilha Grande, RJ, Brazil. Revista Brasileira de Botânica, São Paulo, v. 24, n. 4, p. 389-394, 2001.

COSTA, C.; VANIN, S. A.; CASARI-CHEN, S. A. Larvas de Coleoptera do Brasil. São Paulo: Museu de Zoologia, 1988. 282 p. CPTEC/INPE - CENTRO DE PRECISÃO DO TEMPO E ESTUDOS CLIMÁTICOS/INSTITUTO NACIONAL DE PESQUISAS ESPACIAIS. Programa de Monitoramento Climático em Tempo Real (Proclima). 2012. Available at $<\mathrm{http}$ :// proclima.cptec.inpe.br/>. Accessed in: 22 Sept. 2012.

FRANK, J. H.; LOUNIBOS, L. P. Pytotelmata: terrestrial plants as hosts for aquatic insects communities. Medford: Plexus Publishing, 1983. 293 p.

FREITAS, A. F. N., COGLIATTI-CARVALHO, L.; SLUYS, M. V.; ROCHA, C. F. D. Distribuição espacial de bromélias na restinga de Jurubatiba, Macaé, RJ. Acta Botanica Brasilica, Feira de Santana, v. 14, n. 1 , p. $175-180,2000$. 
GESING, J. P. A. 2008. Macroinvertebrados associados à Vriesea friburgensis Mez (Bromeliaceae) em Floresta Ribeirinha, Santa Maria, RS, Brasil. 2008. 64 f. Dissertação (Mestrado em Biodiversidade Animal) - Universidade Federal de Santa Maria, Santa Maria. 2008.

GIUlietTE, A. M.; NETA, A. L. DO B.; CASTRO, A. A. J. F.; GAMARRA-ROJAS, C. F. L.; SAMPAIO, E. V. S. B.; VIRGÍNIO, J. F.; QUEIROZ, L. P.; FIGUEIREDO, M. A.; RODAL, M. J. N.; BARBOSA, M. R. V.; HARLEY, R. M. Diagnóstico da vegetação nativa do bioma Caatinga. In: SILVA, J. M. C. da; TABARELLI, M.; FONSECA, M. T. da; LINS, L. V. (Org.). Biodiversidade da caatinga: áreas e ações prioritárias para a conservação. Brasília: Ministério do Meio Ambiente: Universidade Federal de Pernambuco, 2003. p. 48-78.

GUIMARÃES-SOUZA, B. A.; MENDES, G. B.; BENTO, L.; MAROTTA, H.; SANTORO, A. L.; ESTEVES, F. A.; PINHO, L.; FARJALLA, V. F.; ENRICH-PRAST, A. Limnological parameters in the water accumulated in tropical bromeliads. Acta Limnologica Brasiliensia, Rio Claro, v. 18, n. 1, p. 47-53, 2006.

GULLAN, P. J.; CRANSTON, P. S. The insects: an outline of entomology. Oxford: Blackwell Publishing, 2005. 440 p.

HADEL, V. F.; CARVALHO, M. A. J. Associação copépodo/ bromélia: relação com o tipo de tanque. Acta Limnologica Brasiliensia, Rio Claro, v. 2, p. 571-586, 1988.

HENRIQUES, R. P. B.; MEIRELLES, M. L.; HAY, J. D. Ordenação e distribuição de espécies das comunidades vegetais na praia da restinga de Barra de Maricá, Rio de Janeiro. Revista Brasileira de Botânica, São Paulo, v. 7, n. 1, p. 27-36, 1984.

JUNCÁ, F. A.; BORGES, C. L. S. Fauna associada a bromélias terrícolas da Serra da Jibóia, Bahia. Sitientibus, Feira de Santana, v. 2, p. 73-81, 2002.

KITCHING, R. L. Food webs and container habitats: the natural history and ecology of phytotelmata. Cambridge: Cambridge University Press, 2000. 448 p.

KITCHING, R. L. Food webs in phytotelmata: "bottom-up" and "top-down" explanations for community structure. Annual Review of Entomology, Palo Alto, v. 46, p. 729-760, 2001.

KROL, M. S.; JAEGER, A.; BRONSTERT, A.; KRYWKOW, J. The semi-arid integrated model (SIM), a regional integrated model assessing water availability, vulnerability of ecosystems and society in NE-Brazil. Physics and Chemistry of the Earth (B), Atlanta, v. 26, p. 529-533, 2001.

LEAL. I. R.; TABARELI, M.; SILVA, J. M. C. Ecologia e conservação da Caatinga. Recife: UFPE/ Ed. Universitária, 2003. $806 \mathrm{p}$.

LEGENDRE, P.; LEGENDRE, L. Numerical Ecology. 3. ed. Amsterdan: Elsevier, 2012. 990 p.

LEME, E. M. C. Bromélias. Ciência Hoje, Rio de Janeiro, v. 3, p. 66-72, 1984

LOPEZ, L. C. S.; D’ELIAS, A. M. A.; IGLESIAS. R. Fatores que controlam a riqueza e a composição da fauna aquática em tanques da bromélia Aechmea bromeliifolia (Rudge) Baker, na Restinga de Jacarepiá-Saquarema/RJ. Oecologia Brasiliensis, Rio de Janeiro, v. 5, n. 1, p. 91-100, 1998.

MCCUNE, B.; GRACE, J. B. Analysis of ecological communities. Oregon: Gleneden Beach, 2002. 304 p.
MERRIT, R. W.; CUMMINS, K. W.; BERG, M. B. An Introduction to the aquatic insects of North America. 4 ed. Dubuque: Kendall/ Hunt Publishing Company, 1996. 1158 p.

MESTRE, L. A. M.; ARANHA, J. M. R.; ESPER, M. L. P. Invertebrate fauna associated to the bromeliad Vriesea inflata of the Atlantic Forest (Paraná State, Southern, Brazil). Brazilian Archives of Biology and Technology, Curitiba, v. 44, n. 1, p. 8994, 2001.

MONTERO, G.; FERUGLIO, C.; BARBERIS, I. M. The phytotelmata and foliage macrofauna assemblages of a bromeliad species in different habitats an seasons. Insect Conservation and Diversity, Hoboken, v. 3, n. 2, p. 92-102, 2010.

NAVAS, C. A.; ANTONIAZZI, M. M.; JARED, C. A preliminary assessment of anuran physiological and morphological adaptation to the Caatinga, a Brazilian semi-arid environment. International Congress Series, Atlanta, v. 1275, p. 298-305, 2004.

OLIVEIRA, C. M. DE; FRIZZAS, M. R. Insetos de Cerrado: distribuição estacional e abundância. Planaltina: Embrapa, Empresa Brasileira Agropecuária, Ministério da Agricultura Pecuária e Abastecimento, 2008. 26 p.

OLIVEIRA, M. G. N.; ROCHA, C. F. D.; BAGNALL, T. A comunidade animal associada à bromélia tanque Neoregelia cruenta (R. Graham) L. B. Smith. Bromélia, Rio de Janeiro, v. 1, p. 22-29, 1994.

OSPINA-BAUTISTA F., ESTÉVEZ-VARÓN, J. V.; BETANCUR, J.; REALPE-REBOLLEDO, E. Estructura y composición de la comunidad de macroinvertebrados acuáticos asociados a Tillandsia turneri baker (Bromeliaceae) em un bosque alto andino colombiano. Acta Zoológica Mexicana, Ciudad de México, v. 20, n. 1, p. 153-166, 2004.

PICADO, C. Les broméliacées épiphytes considérées comme milieu biologique. Bulletin Scientifique de la France et de la Belgique, Paris, v. 7, p. 215-360, 1913.

PINHEIRO, F.; DINIZ, I. R.; COELHO, D.; BANDEIRA, M. P. S. Seasonal pattern of insect abundance in the Brasilian Cerrado. Austral Ecology, Alice Springs, v. 27, n. 2, p. 132-136, 2002.

REITZ, P. R. Ecological aspects of the Bromeliaceae of southern Brazil. The Bromeliad Society Bulletin, Orlando, v. 7, n. 1, p. 3-6, 1957.

RICHARDSON, B. A. The bromeliad microcosm and the assessment of faunal diversity in a Neotropical forest. Biotropica, Malden, v. 31, n. 2, p. 321-336, 1999.

RICHARDSON, B. A.; HULL, G. A. Insect colonization sequences in bracts of Heliconia caribaea in Puerto Rico. Ecological Entomology, Lndon, v. 25, n. 4, p. 460-466, 2000.

ROCHA, C. F. D.; COGLIATTI-CARVALHO, L.; ALMEIDA, D. R.; NUNES-FREITAS, A. F. Bromélias: ampliadoras da biodiversidade. Bromélia, Rio de Janeiro, v. 4, p. 7-10, 1997.

ROCHA, P. L. B.; QUEIROZ, L. P.; PIRANI, J. R. Plant species and habitat structure in a sand dune field in the Brazilian Caatinga: a homogeneous habitat harbouring an endemic biota. Revista Brasileira de Botânica, São Paulo, v. 27, n. 4, p. 739-755, 2004.

RODAL, M. J. N.; SAMPAIO, E. V. S. B. A vegetação do bioma Caatinga. In: SAMPAIO, E. V. S. B.; GIULIETTI, A. M.; VIRGÍNIO, J.; GAMARRA-ROJAS, C. F. L. (Ed.). Vegetação e flora das caatingas. Recife: APNE/CNIP, 2000. p. 11-24. 
RODRIGUES, M. T. Herpetofauna da Caatinga. In: LEAL, I. R.; TABARELIAND, M.; SILVA, J. M. C. (Ed.). Ecologia e conservação da Caatinga. Recife: UFPE/ Ed. Universitária, 2003. p. 181-236.

ROMERO, G. Q. Associações entre aranhas Salticidae e Bromeliaceae: história natural, distribuição espacial e mutualismos. 2005. 233 f. Tese (Doutorado em Ecologia) - Universidade de Campinas, Campinas. 2005.

SANTOS, A. J. Estimativas de riqueza de espécies. In: CULLEN JR., L.; RUDRAN, R.; VALLADARES-PÁDUA, C. (Ed.). Métodos de estudo em biologia da conservação e manejo da vida silvestre. Curitiba: Editora da UFPR, 2003. p. 19-41.

SILVA, A. M.; NUNES, V.; LOPES, J. Culicídeos associados a entrenós de bambu e bromélias, com ênfase em Aedes (Stegomyia) albopictus (Diptera, Culicidae) na Mata Atlântica, Paraná, Brasil. Iheringia, Porto Alegre, v. 94, n. 1, p. 63-66, 2004.
SILVA, N. T. C. Macroinvertebrados bentônicos em áreas com diferentes graus de preservação ambiental na Bacia do Ribeirão Mestre d'Armas. 2007. 113 f. Dissertação (Mestrado em Ecologia) - Universidade de Brasília, Brasília. 2007.

SOUTO, P. C.; SOUTO, J. S.; DE MIRANDA, J. R. P.; DOS SANTOS, R. V.; ALVES, A. R. Comunidade microbiana e mesofauna edáficas em solo sob Caatinga no Semi-Árido da Paraíba. Revista Brasileira de Ciência do Solo, Viçosa, v. 32, n. 1, p. 151-160, 2008.

VANNOTE, R. L.; MINSHALL, G. W.; CUMMINS, K. W.; SEDELL, J. R.; CUSHING, C. E. The river continuum concept. Canadian Journal of Fisheries and Aquatic Sciences, Ottawa, v. 37, p. 130-137, 1980.

WITTMAN, P. K. The Animal community associated with canopy bromeliads of the lowland Peruvian Amazon Rain Forest. Selbyana, Sarasota, v. 21, n. 1.2, p. 48-51, 2000.

ZAR, J. H. Biostatistical analysis. Englewood Cliffs: PrenticeHall, 1996. 818 p. 